\title{
ZNF304 gen ifadesinde artış ve CXCR4'de azalma ile prostat kanserinde anoikis değişebilir
}

\section{Significant increase in ZNF304 and decrease in CXCR4 gene expressions may alter anoikis in prostate cancer}

\author{
Şule Ayla ${ }^{1} \quad$ Gülperi Öktem ${ }^{2} \quad$ Cüneyd Parlayan ${ }^{3}$ \\ ${ }^{1}$ İstanbul Medipol Üniversitesi Tıp Fakültesi, Histoloji ve Embriyoloji Anabilim Dalı, Rejeneratif ve \\ Restoratif Tıp Araştırmaları Merkezi (REMER), İstanbul, Türkiye \\ ${ }^{2}$ Ege Üniversitesi Tıp Fakültesi, Histoloji ve Embriyoloji Anabilim Dalı, İzmir, Türkiye \\ ${ }^{3}$ İstanbul Medipol Üniversitesi Doğa Bilimleri ve Mühendislik Fakültesi, Biyomedikal Mühendislik \\ Anabilim Dalı, Rejeneratif ve Restoratif Tıp Araştırmaları Merkezi (REMER), İstanbul, Türkiye
}

Öz

Amaç: Prostat kanser hücre hattı (DU145) ve prostat normal epitel hücre hatları (RWPE) arasında anoikis mekanizmasını arttıracak veya inhibe edebilecek genlerin analizini yapmak ve kanser gelişiminde olası rolünü incelemek.

Gereç ve Yöntem: Insan prostat epitel hücre hattı (RWPE) ve prostat kanseri hücre hatları (DU-145) Amerikan Tip Kültür Koleksiyonu (ATCC)'den temin edildi. Hücre hatlarının çoğaltılmasında ve sürdürülmesinde RPMI 1640 (Biological Industries) besi ortamı kullanıldı. Transkriptom analizi için RNA izolasyonu yapılarak, kütüphane oluşturuldu, kütüphanenin kantitasyonunun ardından NextSeq500 (illumina) ile sekanslama yapıldı. Dizileme, haritalandırma, bağıl gen ifadeleri ölçümleri gibi biyoinformatik analizler Genomics Workbench v 8 (Qiagen) yazıımı kullanılarak GRCh38 referans sekansı ile yapılmıştır.

Bulgular: RWPE Normal prostat epitel hücre kültürleri ile DU145 prostat kanser hücreleri karşılaştııılığı zaman DU-145 prostat kanser hücre kültürlerinde, ZNF304, PYCARD ve Notch3 gen expresyonlarında anlamlı bir artış $(p<0,05)$ görülürken, CXCR4, Pak3, SerpınB1 gen ekspresyonlarında anlamlı bir azalma $(p<0,05)$ görülmüştür. Sonuç: DU145 prostat kanseri hücre hattında anoikis ile ilişkili önemli gen ekpresyonlarında artış ve azalma gözlemledik. Değişime bağlı olarak hücrelerin anoikisden kaçarak metastatik özellik kazanabileceğini düşündük.

Anahtar Sözcükler: Apoptozis, anoikis, kanser, mezenkimal geçiş.

\section{Abstract}

Aim: To analyze genes that may increase or inhibit the anoikis mechanism between prostate cancer cell line and prostate normal epithelial cell line and examine the possible role of cancer in cancer development.

Materials and Methods: Human prostate epithelial cell line (RWPE) and prostate cancer cell line (DU145) were acquired from ATCC. Both cell lines were maintanied in RPMI 1640 (Biological Industries) medium. Total RNA were isolated and fragmented. Adapters were ligated to prepare RNA library for whole trasncriptome experiments. Statistics and bioinformatics analysis including mapping, clustering, sequencing were done by using Genomics Workbench v 8. (Qiagen) software.

Results: As we compared the normal prostate ephitalial cells (RWPE) and prosatate cancer cells (DU 145); ZNF304,PYCARD ve NOTCH3 were significantly $(p<0.05)$ up-regulated in DU145 cells, on the other hand, CXCR4, PAK3, SERPINB1 genes were significantly down-regulated.

Conclusion: We found that there are significant differential gene expressions in DU-145 cells which may lead to metastatic state via evasion of anoikis process.

Keywords: Apoptosis, anoikis, cancer, mesenchymal transition.

Yazışma Adresi: Şule Ayla

İstanbul Medipol Üniversitesi Tıp Fakültesi, Histoloji ve

Embriyoloji Anabilim Dalı, Rejeneratif ve Restoratif Tıp

Araştırmaları Merkezi (REMER), İstanbul, Türkiye

Makalenin Geliş Tarihi: 16.07.2017 Kabul Tarihi: 24.07.2017 


\section{Giriş}

Malign kanserlerin en önemli özelliklerinden birisi metastaz yetenekleridir. Kanser hücreleri lenf veya venöz dolaşım yolu ile uzak organlara taşınmaktadır (1). İdealize modellerde $1 \mathrm{gr}$ tümör için dolaşıma her gün $10^{6}$ tümör hücresinin döküldüğü/girdiği gözlenmiştir (2). Bir çoğu başta apoptoza olan yatkınlıkları ve aniokise direnç göstermemeleri nedeniyle daha damar içindeyken elimine olurlar $(3,4)$. Hayatta kalan az sayıda hücre grubu ise hedef bölgeye ulaşır, ancak bu hücrelerin de büyük kısmı gerekli çoğalma başarısını gösteremez. Ancak kan, kanser hücrelerine kısa süreli ev sahipliği yapmayı hastalık boyunca sürdürür.

Kanser araştırmalarında son yıllarda kaydedilen gelişmeler, hastalara sunulan tanı ve tedavi yöntemlerinin değişmesine ve sağ kalım sürelerinin artmasına neden olmaktadır. Moleküler biyolojik çalışmaların artması ve teknolojik gelişmelerin çok hızıı ve kolay paylaşılabilir olması da bu gelişmede önemli rol oynamaktadır. Kanser hücrelerinin sağ kalımı, metastaz yeteneği, çevre matriksi ile olan ilişkileri ve farklılaşabilme yeteneği dışında hücre ölüm mekanizmaları da yoğun olarak çalışıımaktadır. Yakın zamana kadar morfolojik tanımlamalarla sınıflandırılan iki hücre ölüm çeşidi nekrozis ve apoptosis olarak bilinmekteydi. Ölçülebilen biyokimyasal özelliklerinin yanında oldukça karmaşık mekanizmaları ile hücre ölümü günümüzde, apoptosis, otofajik hücre ölümü, mitotik katastrofi, nekroptosis, parthanatos, ferroptosis, pyroptosis, pyronekrozis, anoikis, kornifikasyon, entosis ve netosis olarak sınıflandırılmaktadır. Apoptotik hücre ölümünün bir modeli olarak da kabul edilen anoikis; yetersiz hücre- hücre matriksi ilişkisi ile oluşmaya başlayan ve metastaz biyolojisinde rol alan çok önemli bir mekanizma olarak bilinmektedir. Anoikis ilk olarak 1994 yılında Frish ve Francis (5) tarafından tanımlanmış ve o dönemden sonra da kanser ve anoikis inhibisyonu ilişkisi çalışılmaya başlanmıştır. Yeni bir terminoloji olan anoikis eski Yunancada evsiz anlamında kullanılmaktadır ve matrikse yapışamayan (yetersiz hücre-hücre matriks ilişkisi) hücrelerde meydana gelen apoptozisi tanımlamaktadır. Anoikisin varlığı, apoptozis mekanizmasının önemli bölümlerini kontrol eden integrin düzenlemelerini ifade eder, çünkü integrinler in vivo önemli matriks reseptörleridir (5). Anoikis normal deri dokusunda (6) ve kolon epitel hücrelerinde (7) oluşmaktadır. İlginç olarak, embriyogenezisin ilk kavitasyon mekanizmasında önemli bir fizyolojik gelişim rolü oynar (8). Anoikis, hücrelerin displastik büyümeleri ve yanlış lokalizasyonlarda yeni matrikse yapışmasının önlenmesinde organizmanın önemli bir defans mekanizması olarak rol oynar, bu düzenlenme kanser hücrelerinde ve hücrelerin uzak organ metastazlarında dikkat çekicidir (9). Çok sayıda heterojen hücreden oluşan tümör dokusuna ait hücreler, metastaz sürecinde dolaşıma geçme yönünde değişikliklere uğrayarak çoğalmaktadırlar. Bu dönemde sayısız malign hücre dolaşıma geçerken, çok az sayıda hücre, yerleşmek için belirlediği organa göç ederek o bölgede çoğalma şansına sahip olmaktadır. Hücre dışı matrikse bağlanamamak hücre ölümü için bir sebeptir ve dolaşıma geçen ancak tutunamayan hücrelerin pek çoğu anoikis nedeni ile ölmektedir. $(10,11)$. Anoikis direnci tümör invazyon ve metastazında önemli rol oynarken, anoikis duyarlılığı da doku ile bağlantı yapamayan kanser hücrelerinin yok olması ile sonuçlanmaktadır. Bu olay, ekstrasellüler matris bileşenleri $(E C M)$ üzerinde bulunan bağlantı kompleksleri ile ilişkide olan integrinler tarafından düzenlenmektedir ve hücre iskeletinde aktinin kontrol ettiği hücre çıkıntısı sayesinde ekstrasellüler matrise yapışması ve hücre göçü sağlanabilmektedir. Epiteliyal mezenkimal geçiş (EMT) kök hücre özelliklerini belirlenmesinde, hücre göçü özelliğinin ortaya çıkmasında ve adezyon yapan bağlantının bozularak invaziv özellik kazanılmasında rol oynamaktadır. Böylelikle anoikis ile tümör mikro çevresinden kaçış ortaya çıkmaktadır (12). Anoikis direnci tümör metastazı için bir zorunluluktur. EMT tümör hücrelerinin anoikisden kaçınmasına izin verir (13). Tümör hücrelerinin anoikis için direnci ana apoptotik oluşumun inaktivasyonu ve büyüme faktörü/integrin sinyal yolağının aktivasyonunun neden olduğu tümör mikro çevresindeki eşsiz oluşumlar ya da epigenetik değişimler ile sürdürülür (14-16). Prostat kanseri erkeklerde en sık tanı konulan kanserler arasında ikinci sıradayken, kansere bağlı ölümlerde ise beşinci sırada yer almaktadır $(17,18)$.

Bu çalışmada, prostat kanser hücre hattı ve prostat normal epitel hücre hatları arasında anoikis mekanizmasını arttıracak veya baskılayacak genlerin analizi yapılarak kanser gelişiminde olası rolü incelendi.

\section{Gereç ve Yöntem}

\section{Gen analizi}

Insan prostat epitel hücre hattı (RWPE) ve prostat kanseri hücre hatlarında (DU-145), anoikis ile ilişkisi olduğu düşünülen, ZNF304, PYCARD, Notch3, CXCR4, Pak3, SerpınB1gen ekspresyonları araştıııldı.

\section{Hücre kültürü}

Insan prostat epitel hücre hattı (RWPE) ve prostat kanseri hücre hatları (DU-145) Amerikan Tip Kültür 
Koleksiyonu (ATCC)'den temin edildi. DU-145 insan prostat kanseri hücre hattının çoğaltılmasında ve sürdürülmesinde RPMI 1640 besi ortamı (Biological Industries) kullanıldı, 500 ml'lik steril besi ortamının içerisine \%1 oranında penisilin/streptomisin, \%10 ısı ile inaktive edilmiş fetal sığır serumu, \%1 oranında amfoterisin B ve \%1 oranında L-glutamin eklenerek çoğaltıldı. RWPE-1 insan normal prostat epiteli hücre hattının çoğaltılmasında ve sürdürülmesinde ise keratinosit SFM besi ortamı (Invitrogen, 17005-075) kullanıldı. İçerisinde L-glutamin, epiteliyal büyüme faktörü (EGF) ve bovin pitüiter ekstraktı (BPE) bulunan bir kit ile birlikte satılan bu besi ortamına kitte bulunan bu maddeler eklenerek, $37^{\circ} \mathrm{C}$ sıcaklıkta, \%5 CO2 ve nem içeren inkübatörde çoğaltıldı. Hücre hatları canlılık, çoğalma ve enfeksiyon açısından inverted mikroskopta günlük olarak izlendi, flasklarda \%80'in üzerinde hücre yoğunluğu gözlendiğinde hücreler pasajlanarak çoğaltıldı.

\section{Transkriptom Analizi}

\section{RNA izolasyonu}

RNA izolasyonu RNeasy Plus Mini Kit (Qiagen, Lot No:148050825) protokolüne göre yapıldı. Kısaca lizis ve homojenize olmuş hücreler genomik DNA'dan arındırılıp $75 \mathrm{ng} / \mathrm{uL}$ toplam RNA izole edildi. RNA kalitesi UV absorbans birimi spectra Max i3 (Molecular Devices) ile ölçüldü.

\section{Kütüphane oluşturulması}

Kütüphane hazırlığı ve sekanslama TruSeq Stranded RNA LT kit (Illumina, Ref: 15032612, Lot:10037008) ile yapıldı. Kısaca $750 \mathrm{ng}$ toplam RNA önce Ribo-Zero (Illumina Lot:10035196) ile fragmanlara ayrıldı, iki basamakta cDNA sentezi yapıldı (Illumina, Lot: 10035192), 3' terminler adenilasyon edildikten sonra RNA fragmanları özel dizayn edilmiş adaptörler ile bağlandı. Adaptörlere bağlanan diziler kitte tavsiye edildiği üzere PCR ile çoğaltıldı. 10nM Tris- $\mathrm{HCl}$ ve Tween 20 ile karış-tırılarak örnekler havuz haline getirilip normalize edildi.

\section{Kütüphane kantitasyonu}

Oluşturulan kütüphane Kappa library quantification (Illumina, Lot: KK4824) ile real time PCR (CFX Connect, BioRad) cihazinda kantite edildi. $10 \mathrm{uL}$ reaksiyon hacminde $20 \mathrm{pM}$ olarak real time PCR cihazına yüklendi. Ergime eğrileri (melting curves) ve ortalama $\mathrm{Cq}$ skoru=7.20 kalite değerleri olarak belirlendi. Kalite kriterine aykırı değerler elendi.

\section{Sekanslama}

Grupların üçlü replikeleri Nextseq500 (Illumina) cihazı ile 18 saat süre ile sekanslandı. Kümelenme kalitesi llumina tarafindan önerilen minimum 300 bazlık fragmentlar CTE1, CTE2, CTA ve CTL kontrolleri kontrol edildi.

\section{Biyoinformatik analiz}

NextSeq 500 cihazının oluşturmuş olduğu ham veri BioSpace (Illumina) veri tabanı ile "fastq" formatına çevrildi; genetik haritalandırma, kümelendirmeler, dizilemeler ve istatistik analizler Genomics WorkBench (GWB) version 8 (CLC bio, Qiagen) ile GRCh38 referans sekansı ile yapıldı.

\section{Istatistik analiz}

Biyoinformatik analizden sonra çıkan parametrik sonuçlarda reads per kilobase of transcript per million mapped reads (RPKM) değerleri gen ifadeleri hesaplanmasında kullanıldı. RPKM değerleri GWB donanımındaki quantile metoduna göre normalize edildi. T test ile normalize edilmiş gen ifade değerleri gruplar arasında karşılaştırıldı ve $p<0.05$ değeri anlamlı kabul edildi.

\section{Bulgular}

Transkriptom analizi sonuçlarına göre, RWPE normal prostat epitel hücreleri ile DU145 prostat kanser hücreleri arasında yapılan karşılaştırma ile 7506 adet belirgin gen analiz edilerek, bunların içinden 1802 gen apoptozisle ilişkili olarak bulundu, yine bunların içinden 113 gen anoikis ile ilişkilendirildi. Bu 113 gen ekspresyonu arasında belirgin anlamlılık $(p<0.05)$ ifade eden genler Tablo-1'de gösterilmiştir. RWPE normal prostat epitel hücre kültürleri ile DU145 prostat kanser hücreleri karşılaştırıldığı zaman DU-145 prostat kanser hücre kültürlerinde, ZNF304,PYCARD ve Notch3 gen expresyonlarında anlamlı bir artış $(p<0.05)$ görülürken, CXCR4, Pak3, SerpınB1gen ekspresyonlarında anlamlı bir azalma $(p<0.05)$ görüldü.

Tablo-1. DU-145 Prostat Kanser Hücre Kültüründe Gen Ifadesindeki Değişimler $(p<0.05)$.

\begin{tabular}{l|l|c|l|l|l}
\hline $\begin{array}{l}\text { Gen } \\
\text { ifadesinde } \\
\text { artış }\end{array}$ & $\begin{array}{l}\text { Kat } \\
\text { değişimi } \\
\text { (Fold } \\
\text { change) }\end{array}$ & $\begin{array}{c}\mathrm{p} \\
\text { değeri }\end{array}$ & $\begin{array}{l}\text { Gen } \\
\text { ifadesinde } \\
\text { azalış }\end{array}$ & $\begin{array}{l}\text { Kat } \\
\text { değişimi } \\
\text { (Fold } \\
\text { change) }\end{array}$ & $\begin{array}{c}\mathrm{p} \\
\text { değeri }\end{array}$ \\
\hline ZNF304 & 916.3 & $\mathrm{p}<0.01$ & CXCR4 & -44.9 & $\mathrm{p}<0.01$ \\
\hline PYCARD & 843.4 & $\mathrm{p}<0.05$ & PAK3 & -17.9 & $\mathrm{p}<0.05$ \\
\hline NOTCH3 & 233.9 & $\mathrm{p}<0.05$ & SERPINB1 & -13.1 & $\mathrm{p}<0.01$ \\
\hline
\end{tabular}

\section{Tartışma}

Daha önceki çalışmalar, Notch sinyal yolağının prostat kanserinin progresyonunda önemli bir rol oynayabileceğine dair önemli bilgiler vermiştir. Bazı hücre biyolojisine dair çalışmalar aksini iddia etse bile prostat kanserinde Notch aktivitesi özellikle, ileri 
metastatik hastalıklarda artmaktadır (19). Daha ilginç olarak, Notch aktivitesi metastatik tümör örneklerinde, primer tümör örneklerinden daha yüksek gözlenmiştir (20). Yine çalışmalarda, prostat kanseri kök hücre benzeri hücrelerde NF-kB sinyal aktivasyonunu artırarak anoikis direnci oluşturmaktadır (21). Bizim çalışmamızda da DU-145 prostat kanseri hücre hatlarında normal epiteliyal hücre (RWPE) hatlarına kıyasla Notch3 ekspresyonunda önemli bir artış gözlenmiştir. Anoikis direnci ile ilişkili olduğu düşünülen bu artış, özellikle metastatik kanser hücreleri için önemlidir.

Aslan ve ark. (22) tarafından yapılan bir çalışmada zinc finger transcription factor (ZNF304) over kanser metastazlarında önemli bir anahtar rol oynadığı söylenmiştir. Aynı çalışmada ZNF304 gen ekspresyonunun birçok proto-onkogenik yolağı destekleyerek tümör hücresinin yaşamasını, migrasyonunu ve invazyonunu kolaylaştırdığı ve ZNF304'ün, $\beta 1$ integrin ile birlikte Src/fokal adhezyon kinaz ve paxillin regülasyonunu sağlayarak anoikisi engellediği gösterilmiştir (13). Bir başka çalışmada ZNF304'ün normal over ve meme epiteline kıyasla invaziv meme ve over tümör epitelinde artmış olduğu gözlenmiştir $(23,24)$ Çalışmamızda da yaptığımız gen tanımlamaları arasında ZNF304'ün DU-145 prostat kanser hücre serilerinde normal prostat epitel hücre serilerine oranla çok daha yüksek oranda bulunduğu saptanmıştır.

Anoikis, integrin aktivitesinin yoksunluğuna bağlı olarak görülen adheren malign olmayan hücrelerde apoptozisin bir formudur $(5,25)$. Ancak malign hücreler anoikise direnç geliştirir ve bu da metastatik potansiyelin artmasına neden olur (26). İntegrinler, anoikisde ekstrasellüler matriks proteinleri ve hücreler arasında adezyonu sağlayan önemli mediyatörlerdir $(14,27)$. Son zamanlarda yapılan çalışmalarda integrinlerin aktivasyonu, doku dışına çıkışı sırasında ekstrasellüler matriks elemanları ile etkileşimi artırarak ve tümör yayılması sırasında anoikis duyarlılığını azaltarak prostat kanser hücrelerinin metastatik potansiyelini artırmaktadır (28). Eğer adezyonun olmadığı durumlarda kanser hücrelerinin anoikisden kaçışının moleküler mekanizması anlaşıldığı takdirde, kanser hücrelerinin primer tümörden daha uzak metastaz yaparak yayılma prosedürünün anlaşılması için önemli bir adım olduğu düşünülmektedir (12).

Davalieva ve ark. (29) yaptığı bir çalışmada, SerpınB1 protein bozukluğunun prostat kanserinde önemli bir rol oynayabileceği düşünülmüştür. Çalışmamızda SerpınB1 gen ekspresyonlarının DU145 prostat kanser hücre serilerinde anlamlı derecede azaldığını gözlemledik. Serpin B1'in spontan hücre ölümlerini hızlandırdığı, böylece yeni karakterize edilen apoptozis yolaklarının önemli bir parçasını oluşturduğu düşünülmektedir (30).

Rosenbaum ve ark. (31) yaptığı bir çalışmada, prostat kanser hastalarının oluşturduğu homojen bir grupta 6 epigenetik biyoişaretleyicinin (AIM1, CDH1, KIF1A, MT1G, PAK3, ve RBM) önemli bir prognostik değer olduğu gösterilmiştir, çalışmamızda da DU-145 prostat kanser hücre hattında PAK3 gen ifadesinde anlamlı bir azalma gözlenmiştir.

CXCR4 tümör hücrelerinden eksprese edilen oldukça yaygın kemokin reseptörleridir ve 23 farklı kanser türünde belirlenmiştir yine tümörün metastazı ve agresif özelliği ile ilişkilendirilmiştir (32,33). İnsan prostat kanserlerinde, CXCL12 ve CXCR4 ekspresyon seviyelerindeki artış normal ya da benign prostat hiperplazilerindeki dokulardan daha yüksektir (34). Hastalar, tümörlerde CXCR4'ün yüksek ekspresyonuna sahiplerse yaşam süreleri CXCR4'ün düşük seviyelerine sahip hastalara göre daha kısadır (35). CXCL12 ve CXCR4 arasındaki etkileşim, prostat kanserinin kemik ve nöral dokuya metastazında önemli bir rol oynar (36). Kanser gelişimi esnasında, hipoksinin CXCR4 ekspresyonunu artırdığı ve metastazı desteklediği bilinir $(37,38)$. Abblet ve ark. (39) bir çalışmasında anoikis dirençli kanser hücrelerinde CXCR4 ekspresyon oranları anlamlı derecede yüksek bulunmuştur. Kochetkova ve ark. (40) yaptıkları bir çalışmada CXCR4 ve CCR7 kemokin reseptörleri için, anoikisi inhibe ederek malign tümörler ve metastatik kanser mekanizmaları için dikkat çekici bir açıklama yaptıklarını ifade etmişlerdir. Çalışmamızda yapılan çalışmaların aksine DU145 prostat kanseri hücre hatlarında CXCR4 gen ifadesinde bir azalma olduğunu gördük ve bu durumun anoikis direnci ile ilişkili olduğunu düşündük ama bu konuya dair çalışması gereken birçok farklı sinyal yolaklarının da olduğunu fark ettik ve bu yolakların açıklanması halinde kemokin bazlı antikanser aşılarının uygulanmasında çok önemli adımlar atılabileceğini fark ettik.

\section{Sonuç}

Çalışmamızda, DU145 prostat kanseri hücre hattında anoikis ile ilişkili önemli gen ekpresyonlarında artış ve azalma gözlemledik. Değişime bağlı olarak hücrelerin anoikisden kaçarak metastatik özellik kazandığını düşündük. 


\section{Kaynaklar}

1. Sethi N, Kang Y. Unravelling the complexity of metastasis - molecular understanding and targeted therapies. Nat Rev Cancer 2011;11(10):735-48.

2. Chang YS, di Tomaso E, McDonald DM, Jones R, Jain RK, Munn LL. Mosaic blood vessels in tumors: Frequency of cancer cells in contact with flowing blood. Proc Natl Acad Sci U S A 2000;97(26):14608-13.

3. Glinsky VV, Glinsky GV, Glinskii OV, et al. Intravascular metastatic cancer cell homotypic aggregation at the sites of primary attachment to the endothelium. Cancer Res 2003;63(13):3805-11.

4. Berezovskaya $O$, Schimmer AD, Glinskii $A B$, et al. Increased expression of apoptosis inhibitor protein XIAP contributes to anoikis resistance of circulating human prostate cancer metastasis precursor cells. Cancer Res 2005;65(6):2378-86.

5. Frisch SM, Francis H. Disruption of epithelial cell-matrix interactions induces apoptosis. J Cell Biol 1994;124(4):619-26.

6. Polakowska RR, Piacentini M, Bartlett R, Goldsmith LA, Haake AR. Apoptosis in human skin development: Morphogenesis, periderm, and stem cells. Dev Dyn 1994;199(3):176-88.

7. Hall PA, Coates PJ, Ansari B, Hopwood D. Regulation of cell number in the mammalian gastrointestinal tract: The importance of apoptosis. J Cell Sci 1994;107( Pt 12):3569-77.

8. Coucouvanis E, Martin GR. Signals for death and survival: A two-step mechanism for cavitation in the vertebrate embryo. Cell 1995;83(2):279-87.

9. Chiarugi P, Giannoni E. Anoikis: A necessary death program for anchorage-dependent cells. Biochem Pharmacol 2008;76(11):1352-64.

10. Rosenblatt J, Raff MC, Cramer LP. An epithelial cell destined for apoptosis signals its neighbors to extrude it by an actinand myosin-dependent mechanism. Curr Biol 2001;11(23):1847-57.

11. Buchheit CL, Weigel KJ, Schafer ZT. Cancer cell survival during detachment from the ECM: Multiple barriers to tumour progression. Nat Rev Cancer 2014;14(9):632-41.

12. Cao Z, Livas T, Kyprianou N. Anoikis and EMT: Lethal "liaisons" during cancer progression. Crit Rev Oncog 2016;21(34):155-68.

13. Farris JC, Pifer PM, Zheng L, Gottlieb E, Denvir J, Frisch SM. Grainyhead-like 2 reverses the metabolic changes induced by the oncogenic epithelial-mesenchymal transition: Effects on anoikis. Mol Cancer Res 2016;14(6):528-38.

14. Frisch SM, Screaton RA. Anoikis mechanisms. Curr Opin Cell Biol 2001;13(5):555-62.

15. Reddig PJ, Juliano RL. Clinging to life: Cell to matrix adhesion and cell survival. Cancer Metastasis Rev 2005;24(3):425-39.

16. Simpson CD, Anyiwe K, Schimmer AD. Anoikis resistance and tumor metastasis. Cancer Lett 2008;272(2):177-85.

17. Deng G, Ma L, Meng Q, Ju X, et al. Notch signaling in the prostate: Critical roles during development and in the hallmarks of prostate cancer biology. J Cancer Res Clin Oncol 2016;142(3):531-47.

18. Ferlay J, Soerjomataram I, Dikshit R, et al. Cancer incidence and mortality worldwide: Sources, methods and major patterns in GLOBOCAN 2012. Int J Cancer 2015;136(5):E359-86.

19. Shou J, Ross S, Koeppen H, de Sauvage FJ, Gao WQ. Dynamics of notch expression during murine prostate development and tumorigenesis. Cancer Res 2001;61(19):7291-7.

20. Danza G, Di Serio C, Ambrosio MR, Sturli N, Lonetto G, Rosati F et al. Notch3 is activated by chronic hypoxia and contributes to the progression of human prostate cancer. Int J Cancer 2013;133(11):2577-86.

21. Rajasekhar VK, Studer L, Gerald W, Socci ND, Scher HI. Tumour-initiating stem-like cells in human prostate cancer exhibit increased NF-kappaB signalling. Nat Commun 2011;18(2):162.

22. Aslan B, Monroig P, Hsu MC, et al. The ZNF304-integrin axis protects against anoikis in cancer. Nat Commun 2015;17(6):7351.

23. Bowen NJ, Walker LD, Matyunina LV, et al. Gene expression profiling supports the hypothesis that human ovarian surface epithelia are multipotent and capable of serving as ovarian cancer initiating cells. BMC Med Genomics 2009;2(1):71.

24. Casey T, Patel O, Dykema K, Dover H, Furge K, Plaut K. Molecular signatures reveal circadian clocks may orchestrate the homeorhetic response to lactation. PLoS One 2009;4(10):e7395.

25. Kim YN, Koo KH, Sung JY, Yun UJ, Kim H. Anoikis resistance: An essential prerequisite for tumor metastasis. Int J Cell Biol 2012;2012:306879.

26. Jenning S, Pham T, Ireland SK, Ruoslahti E, Biliran H. Bit1 in anoikis resistance and tumor metastasis. Cancer Lett 2013;333(2):147-51.

27. Frisch SM, Ruoslahti E. Integrins and anoikis. Curr Opin Cell Biol 1997;9(5):701-6.

28. Lee YC, Jin JK, Cheng CJ, et al. Targeting constitutively activated beta1 integrins inhibits prostate cancer metastasis. Mol Cancer Res 2013;11(4):405-17.

29. Davalieva K, Kostovska IM, Kiprijanovska S, et al. Proteomics analysis of malignant and benign prostate tissue by $2 \mathrm{D}$ DIGE/MS reveals new insights into proteins involved in prostate cancer. Prostate 2015;75(14):1586-600.

30. Loison F, Xu Y, Luo HR. Proteinase 3 and Serpin B1: A novel pathway in the regulation of caspase-3 activation, neutrophil spontaneous apoptosis, and inflammation. Inflamm Cell Signal 2014;1(6):e462.

31. Rosenbaum E, Begum S, Brait M, et al. AIM1 promoter hypermethylation as a predictor of decreased risk of recurrence following radical prostatectomy. Prostate 2012;72(10):1133-9.

32. Balkwill F. The significance of cancer cell expression of the chemokine receptor CXCR4. Semin Cancer Biol 2004;14(3):171-9.

33. Balkwill F. Cancer and the chemokine network. Nat Rev Cancer 2004;4(7):540-50 
34. Zhang S, Qi L, Li M, et al. Chemokine CXCL12 and its receptor CXCR4 expression are associated with perineural invasion of prostate cancer. J Exp Clin Cancer Res 2008;4(27):62.

35. Akashi T, Koizumi K, Tsuneyama K, Saiki I, Takano Y, Fuse H. Chemokine receptor CXCR4 expression and prognosis in patients with metastatic prostate cancer. Cancer Sci 2008;99(3):539-42.

36. Taichman RS, Cooper C, Keller ET, Pienta KJ, Taichman NS, McCauley LK. Use of the stromal cell-derived factor-1/CXCR4 pathway in prostate cancer metastasis to bone. Cancer Res 2002;62(6):1832-7.

37. Schioppa T, Uranchimeg B, Saccani A, et al. Regulation of the chemokine receptor CXCR4 by hypoxia. J Exp Med 2003;198(9):1391-402.

38. Helbig G, Christopherson KW $2^{\text {nd }}$, Bhat-Nakshatri $\mathrm{P}$, et al. NF-kappaB promotes breast cancer cell migration and metastasis by inducing the expression of the chemokine receptor CXCR4. J Biol Chem 2003;278(24):21631-8.

39. Ablett MP, O'Brien CS, Sims AH, Farnie G, Clarke RB. A differential role for CXCR4 in the regulation of normal versus malignant breast stem cell activity. Oncotarget 2014;5(3):599-612.

40. Kochetkova M, Kumar S, McColl SR. Chemokine receptors CXCR4 and CCR7 promote metastasis by preventing anoikis in cancer cells. Cell Death Differ 2009;16(5):664-73. 